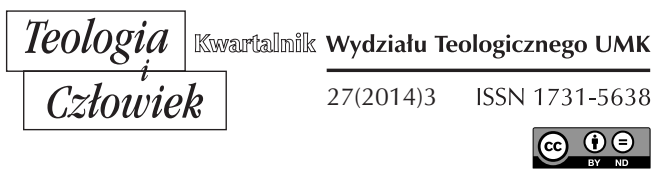

ADAM REGIEWICZ*

CZĘSTOCHOWA

\title{
KONTRKULTURA JAKO SPOSÓB I MIEJSCE PRZEKAZU WIARY
}

DOI: http://dx.doi.org/10.12775/TiCz.2014.034

Przechodząca przez Polskę w latach 90. fala spektakularnych nawróceń muzyków czy nawet szerzej - artystów związanych wcześniej z ruchami kontestacyjnymi (punkowym, hipisowskim), określanych mianem „radykalnych”, rozpoczęła dyskusję nad relacją między kontrkulturą i Kościołem katolickim czy chrześcijaństwem w ogóle. Przywołane zjawisko, będące niewątpliwie fenomenem polskim² na tle procesów

* Adam Regiewicz - dr hab. nauk humanistycznych, prof. nadzw. w Instytucie Filologii Polskiej Akademii im. Jana Długosza w Częstochowie; kierownik Zakładu Teorii Literatury oraz Pracowni Komparatystyki Kulturowej; zajmuje się transkulturowym badaniem średniowieczności, semiotyką i antropologią audiowizualności i nowych mediów oraz relacjami między chrześcijaństwem i popkulturą.

${ }^{1}$ Punktem odniesienia należałoby uczynić nawrócenia muzyków polskich związanych w latach 80. ze sceną punkową, heavymetalową czy hipisowską, którą reprezentowali: Tomasz Budzyński - lider zespołów Armia i Siekiera; Dariusz Malejonek - lider zespołów Houk, Izrael, obecnie Maleo Reggae Rockers, 2 Tm 2,3; Robert „Litza” Friedrich - gitarzysta Turbo, Acid Drinkers, KNŻ, lider 2 Tm 2,3, Arki Noego, Luxtorpedy; Piotr "Stopa" Żyżelewicz - perkusista zespołów Voo Voo, TZN Xenna, Moskwa, Armia, Izrael, 2 Tm 2,3 i innych. Ich świadectwa zebrane przez Marcina Jakimowicza i opatrzone komentarzem o. Dariusza Cichora ukazały się w postaci książkowej pt. Radykalni, Katowice 1997.

${ }^{2}$ Mam świadomość, że używanie „polskości” jako kryterium klasyfikującego 
kulturowych zachodzących w Europie Środkowo-Zachodniej (choć pewnie w Stanach Zjednoczonych nie budziłoby aż takiego zdziwienia) ${ }^{3}$, nie zostało ograniczone jedynie do zamkniętego w czasie okresu postsowieckiego, ale wydaje się nadal istniejącą praktyką, czego wyrazem są pojawiające się raz po raz świadectwa i deklaracje przyjmowania postawy chrześcijańskiej postaci związanych z kulturą alternatywną̨. Z pewnością musi zastanawiać fakt, że ludzie, którzy w latach 70. i 80. głosili hasła anarchistyczne, odrzucali zasady i normy, w tym także religię - a przede wszystkim Kościół katolicki jako narzędzie opresji i zniewolenia, obecnie stają się radykalnymi głosicielami wiary chrześcijańskiej i wartości z niej wypływających, fundamentami „nowej ewangelizacji”, nie rezygnując bynajmniej z przyjętej w młodości formy wyrazu artystycznego, kojarzącego się bardziej z kulturą alternatywną niż powszechnie przyjętym obrazem kultury chrześcijańskiej. Wobec tego warto zadać pytanie o wspólne drogi czy relacje między kontrkulturą i chrześcijaństwem, możliwości głoszenia Ewangelii i przepowiadania Dobrej Nowiny w kodzie kulturowym alternatywy.

może jawić się jako nadużycie, gdyż sytuacje nawróceń postaci związanych z kulturą alternatywną są nadal obecne w kulturze globalnej - szczególnie amerykańskiej, żeby przywołać chociażby postać Alice'a Coopera, słynnego rockmana związanego w latach 80. i 90. z okultyzmem, Briana „Head” Welcha - gitarzysty i lidera grupy Korn, Dave'a Mustaine'a - lidera grupy Megadeth czy wreszcie perkusisty Iron Maiden - Nicko McBraina. Jednak ze względu na dużą liczbę takich sytuacji w podobnym środowisku alternatywnym (w przypadku Czechów będzie to środowisko miejskich intelektualistów) w krótkim odstępie czasu można przyjąć, że kryterium kultury polskiej, w której kontrkultura z powodów politycznych i historycznych zaistniała w inny sposób niż w Stanach Zjednoczonych i Europie Zachodniej, pozwoli lepiej zrozumieć relację ruchów kontestacyjnych i chrześcijaństwa.

${ }^{3} \mathrm{~W}$ amerykańskiej kulturze oraz w życiu publicznym religia jest wszechobecna. „Stany Zjednoczone są najbardziej religijnym krajem Zachodu. Prawie wszyscy Amerykanie wierzą w Boga lub inną siłę wyższą. Ośmiu na dziesięciu jest przekonanych o istnieniu nieba i aniołów, a siedmiu na dziesięciu uważa za pewne lub prawdopodobne istnienie piekła oraz diabła. [...] Co piąty słyszał głos boży, tyle samo jest przekonanych, że zostali cudownie uzdrowieni". M. Wałkuski, Wałkowanie Ameryki, Gliwice 2012, s. 115.

${ }^{4}$ Jednym z ostatnio komentowanych medialnie wydarzeń stało się publiczne wyznanie powrotu do Kościoła Zygmunta „Muńka” Staszczyka, lidera zespołu T.Love. Temat ten pojawił się przy okazji promocji nowej płyty zespołu „Antyidol” Zob. G. Ułamek, Pięć okien, Kraków 2002, oraz P. Sawicki, Bóg dat ci rock and rolla, „Kontrapunkt. Magazyn Kulturalny Tygodnika Powszechnego" (1996) nr 6, dostępny online: http:/ / www.tygodnik.com.pl/kontrapunkt/06/sawicki.html (dostęp 5.04.2014). 


\section{KONTRKULTURA I JEJ STOSUNEK DO ŚWIATA}

Pojęcie kontrkultury można rozumieć dwojako: po pierwsze - jako konkretny ruch, ukonstytuowany około 1969 roku, który sprzeciwiał się zastanej kulturze Zachodu, próbującej tworzyć podwaliny pod kulturę nową, wyzwoloną $\mathrm{z}$ hegemonii kulturowej i proponującą rozproszone formy obecności społecznej, wyznającą alternatywne idee kultury i żyjącą w odmienny od powszechnie przyjętego sposób; po drugie - jako pewien zespół cech charakteryzujący działania nonkonformistyczne wobec norm obowiązujących $\mathrm{w}$ danej rzeczywistości kulturowej. $\mathrm{W}$ tym pierwszym znaczeniu termin „kontrkultura” został świadomie użyty przez Theodore'a Roschaka w książce The Making of a Counter Culture ${ }^{5}$ i skojarzony z bardzo konkretną reakcją społeczną na materialistyczną kulturę Zachodu. Kontrkultura jako ruch społeczny pod jedną nazwą skupiła szereg działań o charakterze alternatywnym, stanowiąc podbudowę ideologiczną ${ }^{6}$ wielu powstających wówczas subkultur, z których najbardziej znacząca - hipisi - ukonstytuowała jej obraz w potocznej mentalności ${ }^{7}$. Wśród charakterystycznych idei można by wymienić koncepcję powrotu do utraconej jedności człowieka, świata przyrody i kosmosu oraz chęć przywrócenia duchowego wymiaru ludzkiej egzystencji, a tym samym zakwestionowanie zachodniego modelu przeżywania życia $\mathrm{w}$ jego wymiarze materialnym ${ }^{8}$. W tym kluczu kwestionowano cały system cywilizacji zachodniej (szczególnie amerykańskiej) oparty na instytucjonalnych formach życia społecznego, których wyrazem były: rodzina, szkoła, sztuka, media masowe, język, systemy pojęciowe, role

T. Roschak, The Making of a Counter Culture: Reflections on the Technocratic Society and Its Youthful Opposition, Doubleday 1969.

${ }^{6}$ Warto zauważyć, że kontrkultura nie była tylko reakcją młodego pokolenia, ale miała także wsparcie w środowisku intelektualnym, żeby wymienić tylko Normana Mailera, Gregory'ego Corso, Williama Burroughsa, Carlosa Castanedę, Jacka Kerouaca, Allena Ginsberga, Normana Browna, Charlesa Reicha, Paula Goodmana, Alana Wattsa, Gridleya Wrighta - poetów, pisarzy, artystów, filozofów, socjologów i innych.

7 Zob. A. Hoffman, Fuck the System, [b.m.w.] 1967; tenże, Revolution for the Hell of It, New York 1968; Ch. Reich, The Greening of America, New York 1970.

${ }^{8}$ Pomijam w tym miejscu genezę ruchów kontrkulturowych, czyli m.in. rosnącą władzę nowych elit politycznych, nieudane konflikty zbrojne w Korei i Wietnamie, nasilający się problem imigrantów i „kolorowych” jako odrzuconych, coraz bardziej konsumpcyjny styl życia, dewaluację mitów cywilizacji zachodniej, zwłaszcza purytańskiej moralności i wartości chrześcijańskich w zderzeniu z rzeczywistością, oraz rewolucję seksualną. A. Kaliszewski, Główne nurty w kulturze XX i XXI wieku, Warszawa 2012, s. 164. 
społeczne, wzory sukcesu i aspiracji życiowych, a także kościoły (przede wszystkim katolicki i luterański - prezbiteriański) ${ }^{9}$. Oficjalnej polityce, propagowanemu stylowi życia społecznego i obyczajowego, którego symbolem były american dream, kariera, stabilizacja, patriarchalny model życia rodzinnego i społecznego, przeciwstawiano idee pacyfizmu, wolnej miłości, nomadyzmu, flower power itp. Już tylko tych kilka właściwości wskazujących na niezakorzenienie kulturowe daje jasno do zrozumienia, że kontrkultura była przede wszystkim działaniem ludzi młodych, powiązanych rówieśniczo i uczestniczących w życiu zbiorowym w sposób okazjonalny, co w dość szybki sposób (mówi się o końcu kontrkultury jako zespołu zjawisk już w 1974 r.) prowadzi do wyczerpania się potencjału tkwiącego $\mathrm{w}$ tym fenomenie kulturowym ${ }^{10}$. Jednak ta „kultura sprzeciwu"11 nie kończy się wraz z kontrkulturą przełomu lat 60. i 70., ale pojawia się jako zespół właściwości ujawniających się raz po raz w różnych formach buntu wobec kultury zastanej - jej wewnętrznych napięć powstających $\mathrm{w}$ wyniku ścierania się ortodoksyjnych norm życia społecznego z koncepcjami wolnościowymi.

Tak rozumiana kontrkultura jest zawsze rodzajem zaangażowanej krytyki wobec kultury dominującej i ma na celu transformację „,istniejących paradygmatów społecznych, naukowych i estetycznych. Jest reformą religijną"12. Za takim pojęciem kontrkultury jako kultury

9 Aldona Jałowiecka grupuje zarzuty stawiane przez kontrkulturę i podkreśla, że celem ataku stały się: system kształcenia (szkoły, ośrodki naukowe), media scentralizowane i podporządkowane integralnym celom polityki i gospodarki oraz technika przenikająca do życia codziennego, która wyznacza tempo konsumpcji i zarazem oddala człowieka od natury. A. Jałowiecka, Drogi kontrkultury, Warszawa 1975.

${ }^{10}$ Jednym $\mathrm{z}$ dość często pojawiających się głosów na temat kontrkultury jest ten o zdradzie ideałów, w ramach której osoby związane niegdyś z tą ideologią stały się później zwolennikami konserwatyzmu. Symbole kontrkultury stały się dość szybko przedmiotem żartów czy elementem folkloru, a z czasem elementem marketingowym (także w uprawianiu polityki). Zob. W. J. Burszta, U źródet buntu. Lata sześćdziesiąte $w$ cyklu śmierci i zmartwychwstania, w: Oblicza buntu. Praktyki i teorie sprzeciwu w kulturze wspótczesnej, red. W. Kuligowski, A. Pomieciński, Poznań 2012, s. 52n.

${ }^{11}$ Pojęcia adversary culture użył Lionel Trilling w książce Beyond Culture, New York 1965, w kontekście rozważań nad buntem literatury modernistycznej wobec materializmu klasy mieszczańskiej, pisząc, że "a primary function of art and thought is to liberate the individual from the tyranny of his culture... and to permit him to stand beyond it in an autonomy of perception and judgment." Tamże, s. 13.

${ }^{12}$ U. Eco, Does Counter-culture Exist?, w: tenże, Apocalypse Postponed, London 1995. Podaję za: W. J. Burszta, U źródet buntu, s. 63. 
alternatywnej czy kultury offu (undergroundu) ukrywa się wiele ruchów reprezentujących różne koncepcje życia i wzory działania: od ruchów feministycznych, ekologicznych, po ugrupowania anarchistyczne. To, co je łączy, to charakterystyczne „niedomknięcie” ideologiczne, antydoktrynerstwo, a w sferze obyczajowej oraz społecznej dążenie do zachowania spontaniczności, niekrępowanego normami, wzorcami, celami itp. Tym samym bardzo często wpisują się one w nowy typ społeczeństwa - postmaterialistycznego hołdującego wartościom, tj. indywidualizm, ekologia, tolerancja, pacyfizm, jakość i zdrowy styl życia ${ }^{13}$. Z drugiej strony, nowy typ społeczeństwa będący konsekwencją działania kontrkultury lat 60 . i 70. może być postrzegany jako kolejna forma autorytaryzmu, wobec której należy przyjąć postawę kontestacji - żeby przywołać wszelkiego rodzaju ruchy anarchistyczne czy fundamentalistyczne. Można by zatem za Kenem Goffmanem powtórzyć, że kontrkultura jest stałym elementem rzeczywistości kulturowej, która przez przekraczanie obowiązujących w danym momencie horyzontów staje się źródłem zmian w historii ${ }^{14}$.

\section{KONTRKULTURA A KOŚCIÓł}

Przyglądając się wzajemnym relacjom między kontrkulturą i Kościołem, trudno wyobrazić sobie bardziej reprezentacyjną parę antagonistów, a ich wzajemne zestawienie w temacie tego artykułu co bardziej gorliwi przedstawiciele każdej ze stron mogliby uznać za prowokację, czy nawet obrazoburstwo. Kontrkultura z towarzyszącym jej sprzeciwem wobec wszelkich form instytucjonalnych z jednej strony i z zainteresowaniem duchowością, która zastąpiła religię rozumianą jako spójny system kosmologiczno-etyczny, z drugiej widziała Kościół jako reprezentanta cywilizacji Zachodu, a to przeciwko tej właśnie hegemonii kulturowej występowała. W tym znaczeniu ruch kontrkultury wystąpił nie tylko przeciw kościołom, podważając znaczenie ich autorytetu $\mathrm{w}$ kwestiach

${ }^{13}$ Wartości te, za Ronaldem Inglehartem, przeciwstawiane są przemijającym wartościom społeczeństwa przedmaterialistycznego (rodzina, religia, naród) i materialistycznego (posiadanie dóbr, ekonomia, władza). R. Inglehart, Pojawienie się wartości postmaterialistycznych, tłum. Sz. Czarnik, w: Socjologia. Lektury, red. P. Sztompka, M. Kucia, Kraków 2006, s. 334-348.

${ }^{14}$ K. Goffman, D. Joy, Counterculture Through the Ages: From Abraham to Acid House, New York 2004. 
społecznych, obyczajowych czy moralnych (czego wyrazem była dokonująca się wówczas rewolucja seksualna), ale także przeciw chrześcijaństwu w ogóle. Miejsce chrześcijaństwa zajęły nowe ruchy religijne, odwołujące się do religijnych aspektów ludzkiej egzystencji i stawiające pytania o sens życia, ale niemające charakteru instytucjonalnego, wręcz przeciwnie, podkreślające indywidualistyczny charakter drogi, jaką należy przebyć w celu doświadczenia religijnego. W kręgu zainteresowań pojawiły się ruchy oparte na kontemplacji, iluminacji, przeżywaniu natury, praktykowaniu magii inicjalnej i ceremonialnej, czy nawet okultyzmu; często proponujące wizję religii bez Boga, akcentujące boskość natury ludzkiej i jej silny związek z siłą kosmiczną (szeroko rozumiany New $A g e)^{15}$. Wśród nich dużym zainteresowaniem cieszą się religie wyrastające z filozofii Wschodu: sufizm, hinduizm czy buddyzm, które uznają co prawda istnienie Istoty Absolutnej, ale nie Boga osobowego, tym samym odrzucając Chrystusa jako Zbawiciela. Jak mówi jeden z nawróconych muzyków, w latach 80. związany z ruchami alternatywnymi: „Jezus Chrystus był dla mnie postacią mityczną, bajkową, a Kościół katolicki kojarzył mi się z martwą religią, z czymś, co nie ma nic wspólnego z Bogiem, $\mathrm{z}$ prawdziwą wiarą. Zacząłem szukać prawdy w filozofiach Wschodu, $\mathrm{w}$ buddyzmie, hinduizmie"16.

Nowe ruchy religijne powstające $\mathrm{w}$ wyniku działania kontrkultury proponowały swoim wyznawcom religijny synkretyzm, w ramach którego każdy może w dowolny sposób wybierać najlepszą dla siebie drogę, przypominając tym samym uczestnika religijnego "szwedzkiego stołu”.

Poszukiwania nowych przestrzeni przeżyć duchowych i parareligijnych, ukierunkowane $\mathrm{w}$ stronę filozofii i systemów religijnych Wschodu, korespondowały z ukazywaniem chrześcijaństwa jako systemu moralno-obyczajowego, którego wartości nie wytrzymywały konfrontacji ze światem. Młode pokolenie zazwyczaj zarzucało „rodzicom” faryzeizm, sprowadzający chrześcijaństwo do zbioru obrzędów czy rytuałów nieprzekładających się na życie codzienne. Pokolenie powojenne, zajęte materialnym odbudowywaniem rzeczywistości, nie znajdowało uznania $\mathrm{w}$ oczach potomnych, a ideały przez nie propagowane: wykształcenie, dobrobyt, pracowitość, skoligacone z wartościami przypisywanymi chrześcijaństwu, tj. prawem, uczciwością, sprawiedliwością, umiarkowaniem itp., stały się obiektem ataku jako mieszczański skompromitowany

${ }^{15}$ P. J. Śliwiński, Kraina Wodnika i okolice, Poznań 1998.

16 Dariusz Malejonek, w: Radykalni, s. 97. 
(m.in. wojną w Wietnamie) paradygmat wiary. Idąc tym tropem, można by zatem stwierdzić, że atak kontrkultury został wymierzony nie tyle w Chrystusa i Jego naukę (zresztą postać Chrystusa jako outsidera kulturowego jest przez ówczesne środowiska kontestujące bardzo dobrze przyjmowana), ile w mieszczańską wersję chrześcijaństwa. O tym mówi jeden z nawróconych Radykalnych:

Odchodziłem od Kościoła, bo niczego w nim nie widziałem. Widziałem ludzi, którzy przychodzą w najdroższych futrach tylko po to, by wepchnąć się do przodu. Dla nich nie było ważne to, by przyjść przed rozpoczęciem Mszy świętej, oni równie dobrze mogli wejść w trakcie kazania. Pokazywało się nowe futro, przylizanego syneczka wypychało do przodu, potem zrywka przed błogosławieństwem... Po cholerę chodzić do takiego kościoła? Żadnej tajemnicy, żadnego sacrum, Msza do odwalenia: przyjść, wstać, otworzyć gębę, zamknąć gębę, usiąść, potem jeszcze raz wstać, przełknąć i do widzenia. Było to dla mnie martwe, nie robiło na mnie żadnego wrażenia. Stwierdziłem, że jeśli Bóg, to owszem, ale nie zinstytucjonalizowany ${ }^{17}$.

Miejsce Dobrej Nowiny zajęła z jednej strony etyka wyrastająca $\mathrm{z}$ ducha protestanckiego, a wyrażająca się w postawie pracowitości, użyteczności, rzetelności, dobrego wychowania, przyzwoitości, szczerości, schludności, punktualności itp., a z drugiej silny moralizm: „pracuj, staraj się, bądź dobry!", bo wiara bez uczynków jest martwa (Jk 2,14-26). Na to wszystko zaś nałożył się drobnomieszczański styl życia, w którym praktyki religijne stały się elementem strukturyzowania życia społecznego (np. kto bogatszy, ten siada w pierwszym rzędzie w wykupionej wcześniej ławce) i obyczajowego (np. obecność w świątyni narzuca pewien sposób wyglądu, długie włosy bądź tatuaż są trudno akceptowalne). „Mentalność ludzi jest taka małomiasteczkowa, wiadomo więc, że jeśli nie chodzisz do kościoła, nie zachowujesz się jak wszyscy i co ważne - nie wyglądasz tak jak wszyscy, to biorą cię na języki. Mnie kojarzyło się to tylko z jednym - doszedłem więc do tego, że trzeba się zbuntować"18.

Wizerunek kościołów, a przede wszystkim Kościoła katolickiego, sprowadzony do roli strażnika prawa - „policjanta” strzegącego nakazów i zakazów, co oczywiste, nie mógł budzić zaufania. Taki obraz Kościoła, wynikający z naleciałości historycznych i uwarunkowań kulturowych, nie

${ }^{17}$ Grzegorz „Dziki” Wacław, w: tamże, s. 48.

18 Tamże, s. 47. 
ukazywał jednak jego istoty, która - jak mówi Konstytucja dogmatyczna o Kościele - jest sakramentem zbawienia ${ }^{19}$, to znaczy jest znakiem działania Boga w świecie, dzięki któremu ludzkość może zostać zbawiona. Nie chodzi zatem o jurydyczne czy moralistyczne rozumienie Kościoła, do którego wciela się masy, rzesze ludzi, narzucając im pewien sposób postępowania, od którego zależy ich zbawienie, ale o takie działanie Kościoła, dzięki któremu człowiek zobaczy prawdziwą miłość Boga do niego i uwierzy, że „Bóg jest Miłością”, przyjmując tym samym Dobrą Nowinę. XIX-wieczny polski filozof Mirosław Dzielski pisał: „W cywilizacji chrześcijańskiej moralność wynika z religii. Wiara w Boga jest tu czymś pierwotnym, czymś, co nadaje tu w ogóle sens. Próba zastąpienia realnego kontaktu z rzeczywistością transcendentną jakimiś pogadankami o wartościach jest nieporozumieniem" ${ }^{\prime 20}$.

Sprowadzenie Kościoła, a tym samym chrześcijaństwa, do moralizmu jest totalnym nieporozumieniem, które w sposób oczywisty rodzi bunt. Wobec kontrkulturowego priorytetu indywidualizmu rodzi się bowiem pytanie: dlaczego przestrzegać wszystkich tych przepisów, dlaczego wykonywać to prawo? Można by powiedzieć, że spod „pospolitej mentalności"21, która tłumiła prawdziwą wartość chrześcijaństwa, nie było widać Jezusa Chrystusa i przeciwko takiemu chrześcijaństwu kontrkultura wyrażała swój sprzeciw.

\section{CHRZEŚCIJAŃSTWO JAKO KONTRKULTURA}

Oczywiście, tak postawiona teza byłaby nie do obronienia, gdyby traktować kontrkulturę sensu stricto jako zjawisko kulturowe przełomu lat 60. i 70., a także - na co zwraca uwagę ks. Tomasz Halik - „powoły-

${ }^{19}$ KKK 849: „Kościół posłany przez Boga do narodów, aby był powszechnym sakramentem zbawienia, usiłuje głosić Ewangelię wszystkim ludziom z najgłębszej potrzeby własnej katolickości oraz nakazu swego Założyciela".

${ }^{20}$ Cyt. za: F. Memches, Pożerając wtasny ogon, czyli krótki szkic o dekadencji stanu trzeciego, „Fronda” nr 23-24, s. 209.

${ }^{21}$ Pojęcie to wprowadza ks. Tomasz Halik, ukazując różnicę w postrzeganiu chrześcijaństwa: „Tam, gdzie religia była tłumiona nie przez "pospolitą mentalność", ale przez represyjną ideologię, odżywała, ponieważ brała na siebie rolę »kontrkultury«, a to jest coś więcej niż tylko zastępowanie roli opozycji politycznej". Odkupieni, to znaczy wolni. Z ks. Tomaszem Halikiem rozmawia Jan Jandourek, tłum. A. i J. Babuchowscy, „Tygodnik Powszechny" (2002) nr 25. 
wanie się na kontrkulturę wciągnęłoby Kościół w bardzo obskuranckie towarzystwo ludzi zgorzkniałych, którzy - niezdolni do życia w trudnych warunkach wolnego społeczeństwa oraz do samodzielnego myślenia i dokonywania odpowiedniego wyboru $\mathrm{z}$ niewyczerpanych wręcz możliwości pluralizmu kulturowego - nostalgicznie zerkają w stronę dawnego porządku". W niniejszym artykule chodzi raczej o wskazanie kontrkulturowych właściwości obecnych w świadomym przeżywaniu chrześcijaństwa przez pewną grupę związaną ze środowiskiem artystyczno-muzycznym w Polsce i nie chodzi tu o ruch młodzieżowy (np. pokolenie JP II) o charakterze religijnym, który wpisywałby się w „logikę wahadła", ale raczej o pewien zbiór różnych działań w Kościele, świadczących o dokonującej się zmianie ${ }^{22}$.

$\mathrm{Na}$ początku warto zwrócić uwagę na kontekst pojawiania się w kulturze tematyki chrześcijańskiej, tylko pozornie bowiem można mówić o stabilności relacji pomiędzy kulturą a chrześcijaństwem, podobnie jak relacja Kościół - państwo przypomina raczej „pakt o nieagresji” niż znormalizowane stosunki. Z jednej strony kultura, silnie dziś zmedializowana, publikuje treści o charakterze religijnym $\mathrm{w}$ postaci transmisji mszy i uroczystości sakralnych, emituje programy i filmy o takiej tematyce, z drugiej zaś propaguje zgoła odmienny obraz świata, ukazujący rzeczywistość zbrutalizowaną, cyniczną, opartą na przyjemnościach hedonistycznych, usprawiedliwiającą zjawiska naganne społecznie itp. Tym samym eksponuje ona rozbrat pomiędzy życiem religijnym (zarezerwowanym dla świątyni i czasu świętego) a życiem codziennym, wskazując na odmienność tychże płaszczyzn i wzajemną nieprzystawalność. Każda zaś próba łączenia obu tych rzeczywistości zostaje okrzyknięta fundamentalizmem i wiąże się z oskarżeniem o zamach na wolność religijną jednostki. W tym kluczu można by przywołać wypowiedzi niektórych artystów (niekiedy nawet niezwiązanych z chrześcijaństwem) na temat obecnej dziś chystianofobii.

Nikomu nie przeszkadza bycie Żydem lub muzułmaninem. Ale gdy tylko ktoś przyzna się otwarcie do chrześcijaństwa, natychmiast jest atakowany. [...] Ci sami dziennikarze nie czepiają się kogoś, kto dręczy swojego psa lub z powodu morderstwa powinien siedzieć $\mathrm{w}$ więzieniu.

${ }^{22}$ O kontrkulturze chrześcijańskiej jako ruchu społecznym i alternatywie kulturowej pisała Małgorzata Bilska w artykule Pokolenie-marzenie. Chrześcijańska kontrkultura XXI wieku, „Więź” (2006) nr 12, s. 74-84. 
Ale jeśli natrafią na człowieka, który uznaje Chrystusa za swojego Pana, traktują go jak kozła ofiarnego. Gdzie my żyjemy?²3

W podobnym duchu na temat odrzucenia chrześcijaństwa i jego konstytutywnej roli w kulturze wypowiada się Lech Majewski, reżyser filmowy, który mówi: „Media potrzebują zachłyśnięcia się jakimś newsem, byle czym, byle tylko dać krótką informację, że ktoś zrobił coś skandalicznego, często związanego z religią - ale tylko jedną, bo innych się nie tyka. Na chrześcijaństwie wszyscy się wyżywają i mówią, że są odważni"24, wpisując się w dość powszechne przekonanie, że dziś prędzej otrzyma się dofinansowanie na film o wielokrotnym mordercy niż o życiu Matki Teresy z Kalkuty ${ }^{25}$. Tym samym można powiedzieć, że publiczne deklarowanie swojej przynależności do Chrystusa stanowi przejaw jednej z konstytutywnych cech kontrkultury, jaką jest występowanie przeciwko głównemu nurtowi istniejącemu w danym momencie kulturowym.

Chrześcijaństwo jawi się w zsekularyzowanym i liberalnym świecie niczym barbarzyństwo, które nie jest w stanie pojać dobrodziejstw cywilizacji z jego kultem wolności, ciała, wyzwolenia seksualnego, konsumeryzmu, ekonomizacji i utylitaryzmu w kontaktach międzyludzkich i innych. To te właśnie zdobycze cywilizacji konstytuują dziś konstrukcję ponowoczesnego autorytaryzmu uobecniającego się w zjawiskach kultury masowej, popkultury czy ponowoczesności właśnie. Normą życia społecznego staje się anonimowość relacji międzyludzkich, pozostających w przypadkowych kontaktach (umownych, przelotnych i sporadycznych), podporządkowanie zmechanizowanemu rytmowi pracy i budowanie własnej tożsamości w oparciu o konsumpcję oraz przynależność „firmową”. Kryterium postępu i sukcesu jednostek oraz całych społeczeństw staje się konsumpcja, która definiuje w ten sposób kategorię wolności: „kupuję, więc jestem”26.

${ }^{23}$ Co ciekawe, ta niezwykła wypowiedź padła z ust Gene'a Simmonsa, lidera zespołu Kiss, oskarżanego niegdyś o obrazoburstwo religijne, okultyzm i wypowiedzi antyreligijne. Wokalista Kiss o chrystianofobii, http:/ / wpolityce.pl/kosciol/98529-wokalista-kiss-o-chrystianofobii (dostęp 7.04.2014).

${ }^{24}$ Niewiarygodne, ile jest banatu we wspótczesnej sztuce, Z Lechem Majewskim rozmawia Karolina Stankiewicz, http://stopklatka.pl/-/79583439,lech-majewski-dla-stopklatki-niewiarygodne-ile-jest-banalu-we-wspolczesnej-sztuce (dostęp 7.04.2014).

${ }^{25}$ Kwestia podniesiona podczas rozmowy z Krzysztofem Zanussim na Jasnej Górze w czasie konferencji Kieślowski czyta Dekalog: 25 lat w dniu 12 grudnia 2013 r.

${ }^{26} \mathrm{O}$ tej nowej hierarchii społecznej opartej na konsumpcji pisze Zygmunt Bauman w książce Ponowoczesność jako źródto cierpień, Warszawa 2000. 
Obiecując natychmiastowe szczęście, konsumeryzm jest także narzędziem nowej demokratyzacji społeczeństwa, które poza dostępem do dóbr (materialnych czy komunikacyjnych) nie uznaje struktury hierarchicznej. To rzeczywistość, w której odrzuca się miarę i kryteria etyczne, podkreślając indywidualne - moralne postawy wobec świata. W konsekwencji sytuacja ta prowadzi do rozmycia granic pomiędzy dobrem i złem, usprawiedliwiając wszystkie zachowania, czego świetnym przykładem jest kulturowa fascynacja obcością, celebracja tego, co niedefiniowalne, czy zniesienie opozycji: męskie - kobiece, dojrzałe - niedojrzałe, człowiek - zwierzę, biologiczne - techniczne, realne - wirtualne i innych na rzecz transgresji, w czym celuje ideologia gender ${ }^{27}$. W tym kluczu można także rozumieć popkulturową fascynację ciałem i seksualnością, wokół których konstruuje się dziś dyskurs tożsamościowy - jako podstawowych kategorii doświadczania rzeczywistości - oraz wymóg coraz silniejszego przeżywania tejże fizyczności poprzez coraz mocniejsze doznania (stąd tendencja do okrucieństwa, wydarzeń ekstremalnych, bombardowanie sygnałami oddziałującymi na zmysły itd.).

Już tylko tych kilka refleksji na temat kultury współczesnej ukazuje całkowitą niemożność obecności Ewangelii Jezusa Chrystusa w jej dyskursie. Paradoksalnie, zdobycze kontrkultury lat 60. i 70. w postaci haseł indywidualizmu, liberalizmu moralnego, ucieczki od wielkich religii ku nieokreślonej duchowości oddały świat w ręce konsumeryzmu, który ma być odpowiedzią na wszystkie te potrzeby ${ }^{28}$. Wobec tego jedynym bastionem „nierynkowości” wydaje się właśnie chrześcijaństwo ${ }^{29}$, tym samym postawa chrześcijańska jawi się dziś jako wyzwanie rzucone tym właśnie formom autorytaryzmu. W takim kontekście można rozumieć wypowiedź Dariusza Basińskiego, lidera grupy teatralnej Mumio, który mówi w jednym z programów:

Muszę powiedzieć, że zawsze lubiłem się sprzeciwiać głównemu nurtowi, czy to w muzyce, czy też w sztuce. Główny nurt, niestety, to pomijanie słowa Jezus - słowa, które jest wszędzie w Eucharystii

27 M. Krajewski, Kultury kultury popularnej, Poznań 2003, s. 105-125.

${ }^{28}$ Zagadnienie to było już wielokrotnie omawiane z różnych perspektyw, począwszy od filozofii, przez antropologię kulturową, socjologię, skończywszy na psychologii. Ciekawy obraz różnych przestrzeni konsumpcji daje G. Ritzer w książce Magiczny świat konsumpcji, tłum. L. Stawowy, Warszawa 2001.

${ }_{29}$ T. Szendlak, Supermarketyzacja. Religia i obyczaje seksualne młodzieży w kulturze konsumpcyjnej, Wrocław 2008, s. 5n. 
i przegania wszelkie demony. Ja jestem "offowy" i to mi odpowiada, na zasadzie buntu przeciwko takiej rzeczywistości, która mnie uwiera. Nie chcę rzeczywistości, która eliminuje Jezusa i eliminuje Krzyż. Noszenie ze sobą Jezusa to również zgoda na bycie prześladowanym, świadczenie o nim w swoim życiu ${ }^{30}$.

W sposób jeszcze bardziej wyrazisty wiąże chrześcijaństwo z działaniami kontestacyjnymi „Muniek” (Zygmunt Staszczyk), opowiadając o swoim powrocie do Kościoła. Zwraca on uwagę, że w latach 80 . w refleksji nad rzeczywistością nie było podziału na scenę i widownię, tylko obie te przestrzenie obejmowało wezwanie do buntu, podobnie dziś bycie chrześcijaninem wymaga otwartej deklaratywności w życiu prywatnym ${ }^{31}$. Przyznawanie się do Chrystusa staje się dziś wyrazem radykalności, w którym uobecnia się kontrkulturowy prymat indywidualności względem istniejących powszechnych ograniczeń wynikających z mentalnych, społecznych czy obyczajowych wyobrażeń. Wyznanie wiary w Jezusa Chrystusa to dziś odważny krok w kierunku nonkonformizmu, jak wyznaje Grzegorz „Dziki” Wacław:

Chrystus jest tak radykalny, jak nie był nikt nigdy na świecie. Moje nawrócenie trwa, dokonuje się cały czas. Nawracać się muszę każdego dnia. To jest radykalizm. Można sobie powiedzieć: „Jestem anarchistą", ale twój anarchizm ujawnia się tylko od demonstracji do demonstracji. Natomiast tu, by być człowiekiem wiary, musisz walczyć z sobą przez cały dzień. Pokusy przychodzą jedna za drugą. Uważam, że większym radykalizmem jest walka ze sobą samym niż rzucanie kamieniami na ulicy ${ }^{32}$.

Nie ma bowiem nic bardziej radykalnego od Kazania na Górze, nazywane jest przez protestantów „Mojżeszem do kwadratu”, które

${ }^{30}$ Mumio nie wstydza się Jezusa, http://www.mt1033.pl/mumio--jadwiga-i-dariusz-basinscy,246,zz.html (dostęp 8.04.2014).

31 „Wtedy też wstydziłem się chodzić do kościoła. Teraz mi to przeszło i chodzę. Chociaż jestem daleki, kurewsko daleki od bycia perfekt, ale walczę, normalnie walczę jak człowieczyna i jestem zakumplowany z Bogiem. [...] Jestem wierzącym, religijnym facetem, ale nie chcę o tym za dużo gadać, bo nie lubię się tym chwalić. Boję się, że za rogiem dopadnie mnie jakaś pokusa, że upadnę. Ale też nie wstydzę się przyznać, że chodzę do normalnego polskiego kościoła, nawet jeśli jakiś ksiądz pieprzy tam głupoty, bo nie dla niego tam poszedłem, ale dla Boga". Muniek, Jestem skumplowany z Bogiem, http://kultura.dziennik.pl/artykuly/ 192392,muniek-jestem-skumplowany-z-bogiem. html (dostęp 8.04.2014).

${ }^{32}$ Grzegorz „Dziki” Wacław, w: Radykalni, s. 94. 
przez samo duchowieństwo jest często obłaskawiane, zmiękczane i interpretowane $\mathrm{w}$ kluczu metaforycznym. A przecież Chrystus nie mówi tam w przypowieściach, ale ukazuje na wzór Synaju Nowe Przymierze - nowe prawo Miłości. Ten obraz „nowego człowieka”, który ukazuje Ewangelia św. Mateusza, wzywa każdego do stawania w prawdzie i dlatego może oburzać, jest to bowiem moment - jak powiedział ojciec Paneloux z Dżumy Alberta Camusa - w którym „trzeba we wszystko uwierzyć albo wszystkiemu zaprzeczyć. A któż spośród was ośmieliłby się wszystkiemu zaprzeczyć?" ${ }^{\prime 33}$. Podobieństwo w radykalizmie widzi także Tomasz Budzyński, który mówi: „Bycie chrześcijaninem wymaga, aby "stanąć w prawdzie" wobec samego siebie i świata. Podobnie rock - jest formą szczerej wypowiedzi. Dobra muzyka musi być autentyczna. Mówi się, że rock and roll to bunt. Ale czym jest radykalizm rocka w stosunku do radykalizmu Ewangelii?"34.

Trudno ukrywać, że wobec chrześcijaństwa sensu stricto takie samo oburzenie wyrażają ateiści, agnostycy, jak i „cywilizowani” katolicy, którzy przyjęli drobnomieszczański ersatz za wiarę Abrahama. Wszak jedni i drudzy, mając przed oczami wizerunek Jezusa z obrazka z Pierwszej Komunii - niebieskookiego, uśmiechającego się z rączką na sercu - odrzucają skandal i zgorszenie krzyża, a tym samym nie przyjmują Dobrej Nowiny o tym, który pokonał śmierć, czyli wszystkie zniewolenia człowieka, w które ten popadł w wyniku niezgody na wolę Bożą. Jednak przyjęcie takiej postawy wiąże się z prześladowaniem, o czym przypomina sam Chrystus, mówiąc: „Jeżeli Mnie prześladowali, to i was będą prześladować" (J 15,20). To jest ten sam rodzaj wygnania czy wypędzenia ze społeczności, jaki towarzyszył zjawiskom kontrkulturowym - oburzenie wyrażane przez drobnomieszczański styl życia, w który wymierzone były działania kontestacyjne, towarzyszy także „katolickiej kontrkulturze” ${ }^{\prime 35}$. Mają tego świadomość ci, którzy świadomie deklarują swoje chrześcijaństwo, mówiąc: „Radykalizm pójścia za Jezusem jest radykalizmem wzięcia na siebie krzyża”. Mówić dziś w świecie

33 A. Camus, Dżuma, tłum. J. Guzf, Warszawa 1967, s. 192.

${ }^{34}$ P. Sawicki, Bóg dat Ci rock and rolla..., http://www.tygodnik.com.pl/kontrapunkt/06/sawicki.html (dostęp 5.04.2014).

${ }^{35}$ Pojęcie w znaczeniu negatywnym wprowadzone przez Adama Szostkiewicza na określenie fali radykalnego katolicyzmu, który rzekomo sprzeciwia się linii „dialogu” $\mathrm{i}$ "tolerancji” wypracowanym przez Jana Pawła II. A. Szostkiewicz, Więcej Piusa, mniej Jana Pawta, „Polityka” (2009) nr 8, s. 18-20. 
obiecującym natychmiastową gratyfikację, przyjemność, szczęście jest podobnie jak 2000 lat temu „zgorszeniem dla żydów i głupstwem dla pogan”, ale "nie ma chrześcijaństwa bez krzyża. Teraz mówi się: sukces, kariera, a wiesz, że największą karierę zrobił Jezus, idąc na krzyż"36. To znaczy, że prawdy o krzyżu (przyjmowaniu cierpienia i zła jako woli Bożej) nie chce przyjąć ani „katolickie” społeczeństwo masowe wychowane w duchu pobożności ludowej (religijności naturalnej), dla którego religia jest przede wszystkim formą pewnej obrzędowości wyznaczającej porządek czasowy i przestrzenny życia, ani tym bardziej świat pogański - zdesakralizowany, dla którego cierpienie jest z zasady czymś antyhumanistycznym, a więc nadaje się tylko do odrzucenia. „Z punktu widzenia tak modnego dziś marketingu wypada On [Chrystus - A. R.] najsłabiej. Atena spektakularnie wyskakuje z głowy Zeusa, Światowid ciska piorunami, Wisznu przedstawiany jest jako pan śmierci z czaszkami wokół głowy. A Jezus na kolanach myje stopy uczniów... Świat twierdzi przez cały czas, że przegral" ${ }^{\prime \prime 3}$.

To odrzucenie przybiera różny, czasem bardzo gwałtowny charakter, o czym niejednokrotnie mówią przedstawiciele tego środowiska, wskazując zarówno na samą branżę artystyczną, w której się poruszają, jak i na publiczność, do której kierują swój przekaz. Mówią oni o ostracyzmie w swoim środowisku, oskarżeniach o koniunkturalizm, postrzeganiu w kategorii dziwactwa czy idiotycznej dewocji, a także ataku mediów na nich samych oraz ich rodziny. Podobne odrzucenie spotyka ich ze strony masowej publiczności, która jest zdolna do zachowań agresywnych: plucia, wyzywania, czy nawet pobicia ${ }^{38}$. Jednocześnie doświadczeniu prześladowania i odrzucenia towarzyszy podobne jak w kontrkulturze przekonanie, że odnowa świata przychodzi właśnie przez przemianę duchową, która domaga się wyrzeczenia, zniszczenia starego porządku - materialnego, cielesnego:

Uważam, że żyjemy w czasach ostatecznych. Sytuacja wygląda teraz tak jak w czasach pierwszych chrześcijan, gdy cały świat dookoła był pogański i chrześcijanie stanowili tylko małe enklawy. Obecnie cały świat, media, rządy są z powrotem pogańskie, a właściwie neo-

${ }^{36}$ Dariusz Malejonek, w: Radykalni, s. 122.

37 Tomasz Budzyński, w: tamże, s. 12n.

${ }^{38}$ Mówią o takich sytuacjach zarówno bohaterowie książki Radykalni: Dariusz Malejonek, Tomasz Budzyński czy Grzegorz „Dziki” Wacław, jak i Robert „Litza” Friedrich czy Michał Lorenc w udzielanych wywiadach. 
pogańskie, a chrześcijaństwo jest znowu znakiem sprzeciwu. Myślę, że chrześcijaństwo znowu się rozszerzy mocą Ducha Świętego, który jest teraz wylany na Kościół. Chrześcijaństwo jest płynięciem pod prąd. Pod prąd tego ścieku, którym płyną śmiecie, płynięciem do źródeł ${ }^{39}$.

\section{KU WOLNOŚCl - PODSUMOWANIE}

Rozważając niezwykle nośną w ostatnich latach metaforę "chrześcijańskiej kontrkultury", autor oparł niniejszą refleksję na fenomenie polskiej muzycznej sceny alternatywnej (czy szerzej - środowisku artystycznym), która będąc w latach 80. głosem pokolenia No Future (spadkobierców kontrkultury w wydaniu punkowym), dekadę później przeżyła nawrócenie i stała się głosem niezależnych artystów na temat chrześcijaństwa. I nie chodzi tu bynajmniej o wskazanie nowych przestrzeni oddziaływania chrześcijaństwa (choć z pewnością na temat nowej ewangelizacji można by przy okazji tego tematu powiedzieć), ale przede wszystkim o spojrzenie na chrześcijaństwo jako ożywczego Ducha, który wieje przez świat i zmienia jego oblicze. Na tej płaszczyźnie wydają się spotykać chrześcijaństwo i kontrkultura, którą za wskazaniami kulturoznawców można sprowadzić do kilku charakterystycznych właściwości ${ }^{40}$. Idąc tym tropem teoretycznym, można zobaczyć, w jaki sposób chrześcijaństwo rozumiane nie jako religia czy filozofia, a już na pewno nie moralizm, ale przede wszystkim jako wydarzenie - autentyczne doświadczenie Jezusa Chrystusa, staje się współcześnie takim właśnie działaniem w kulturze.

Wobec powszechnej desakralizacji i chrystianofobii przyznawanie się do Jezusa Chrystusa i deklarowanie postawy chrześcijańskiej jawi się z jednej strony jako działanie sprzeciwiające się (czasem wyłącznie na poziomie mentalnym, choć wobec działań legislacyjnych w Europie

39 Dariusz Malejonek, w: Radykalni, s. 123n.

${ }^{40}$ Kevin Goffman wymienia trzy takie fundamentalne zasady: prymat indywidualności kosztem konwencji społecznych i ograniczeń płynących ze strony rządzących; sprzeciw wobec wszelkim formom autorytaryzmu oraz otwartość na zmiany w zakresie jednostkowym i społecznym. K. Goffman, D. Joy, Counterculture Through the Ages, s. 29. Nieco inaczej formułuje te zasady Wojciech J. Burszta, wymieniając: dążenie do radykalizmu w sposobach wyrazu siebie; autentyczną głęboką komunikację międzyludzką; różnorodność wyrazu; występowanie przeciw głównemu nurtowi istniejącemu w danym momencie kulturowym oraz doświadczenie wygnania czy wypisania się. W. J. Burszta, U źródet buntu, s. 67. 
dotyczących związków partnerskich, aborcji, in vitro itp. wymaga także konkretnego oporu) ograniczeniom rządzących, z drugiej zaś jako świadectwo dające prymat indywidualności. W obu przypadkach głos chrześcijanina w świecie zsekularyzowanym jest głosem świadka wiary, bez którego nie można spotkać Chrystusa. Dlatego tak istotny wydaje się radykalizm wpisany w postawę kontrkulturową, a zarazem tak bliski pierwotnemu chrześcijaństwu. Ten skandal krzyża, surowość i radykalizm Kazania na Górze jawią się w świecie „kultury instant”, kultury udawania, pozoru jako rzucone wyzwanie. Ten radykalizm objawia się także w głoszeniu kerygmatu - Dobrej Nowiny w sposób czysty, bezpośredni, który pozwala nawiązać bezpośrednią, głęboką relację ze słuchającym. To przekaz niezmącony przypowieściami, bajkami, anegdotami czy metaforami, ale donośny głos, że tylko Jezus Chrystus jest Panem i nie ma innego - nawet za cenę odrzucenia, co poświadczają cytowani bohaterowie niniejszego artykułu. Kerygmat bowiem wprost odnosi się do sytuacji egzystencjalnej człowieka, który z powodu grzechu pozostaje w niewoli diabła, a w którą to wchodzi Jezus Chrystus, „aby uwolnić tych wszystkich, którzy całe życie przez bojaźń śmierci podlegli byli niewoli" (Hbr 2,15). Ta bezpośredniość i prostota Dobrej Nowiny jest słowem, pozwalającym patrzeć na chrześcijaństwo jako rodzaj działania kontrkulturowego, o czym wspomina jeden z Radykalnych: „Przez całe swoje życie chciałem być wolny. Byłem punkowcem i anarchistą dlatego, że łaknąłem prawdziwej wolności, ale zamykało mnie to w jakimś schemacie i ograniczałem się sam. Dopiero po nawróceniu tę wolność otrzymałem za darmo" ${ }^{\prime 1}$.

To głębokie pragnienie człowieka, aby być wolnym od strachu, lęku o własne życie - o rodzinę, dom, pracę, szczęście itp., które w rzeczywistości napędza zarówno wszelkie mechanizmy konsumeryczne, jak i działania kontrkulturowe, znajduje swoje "miejsce odpoczynku” w Jezusie Chrystusie. Dlatego też można powiedzieć, że kultura alternatywna jako kultura offu - ta znajdująca się poza głównym obiegiem kulturowym, ta nieelegancka, wykraczająca poza dobre obyczaje i sprzeciwiająca się drobnomieszczańskiemu stylowi życia, staje się dziś naturalnym sprzymierzeńcem chrześcijaństwa w doświadczeniu odrzucenia, zgorszenia, poszukiwania autentyczności, prawdy i wolności.

${ }^{41}$ Grzegorz „Dziki” Wacław, w: Radykalni, s. 88. 
Streszczenie. Przyglądając się nurtom i kierunkom rozwoju globalnej kultury poddanej silnej presji medializacji, można zaobserwować coraz wyraźniejszą tendencję do desakralizacji praktyk kulturowych. Podobnie w środowisku otwartym na doświadczenie religijne ucieka się przed jawną deklaracyjnością wiary, a proces ten można by nazwać dechrystianizacją rzeczywistości „posolonej”. Dominujący dziś nurt kulturowy wyznaczający wzorce i normy zachowań człowiekowi żyjącemu w globalnej ekumenie dokonuje nieustannej redukcji myślenia w kategoriach wiary. Na tym tle niezwykle interesująca wydaje się przestrzeń kontrkultury, która w swej istocie nie tylko odnosi się do sprzeciwu wobec kultury zastanej, odrzucając lansowane wzory zachowań, ale także wyraża się w przekonaniu, że naprawa świata nie jest zadaniem społecznym i politycznym, lecz duchowym. Na przykładzie fenomenu polskiego środowiska artystów związanych ze sceną muzyczną oraz środowiskiem szeroko pojętej alternatywy artykuł pokazuje podobieństwa pomiędzy właściwościami kontrkultury i świadomym przeżywaniem chrześcijaństwa we współczesnej rzeczywistości.

Słowa kluczowe: kontrkultura; świadectwo; przekaz wiary; nowa ewangelizacja; polska scena alternatywna.

Summary: Counterculture as a Space for Religious Discourse and Transmission of the Faith. Looking at the developments and trends of global culture subjected to strong medialisation pressure, can be seen more and more pronounced tendency to desacralization cultural practices. Similarly, in an open environment for religious experience there is escaping from overt avowal of faith, and the process can be called dechristianization of 'salted' society. The dominant trend today defining cultural patterns and norms of behavior of a man who lived in the global ecumenical made constant thinking in terms of a reduction in the faith. Against this background, it seems very interesting counterculture space, which in its essence not only refers to the existing cultural opposition, rejecting promoted patterns of behavior, but also expressed the belief that the repair of the world is not the task of the social and political, but spiritual. For example, the phenomenon of Polish artists associated with the music scene and the wider community alternatives article shows the similarities between the properties of the counterculture and the conscious experience of Christianity in contemporary reality.

Keywords: counterculture; testimony of faith; the new evangelization polish alternative scene. 
